\title{
PERBEDAAN PENGARUH OLAHRAGA TERHADAP TOLERANSI STRES PSIKOLOGIS MAHASISWA FAKULTAS KEDOKTERAN UNIVERSITAS MUHAMMADIYAH MALANG
}

\author{
Yusufa Ibnu Sina Setiawan ${ }^{1}$, Thonthowi Djauhari ${ }^{2}$, Anisa Hanifwati ${ }^{3}$ \\ Fakultas Kedokteran Universitas Muhammadiyah Malang, J1 Bendungan Sutami No. 188A, Kota Malang, \\ Kode Pos 65144, Indonesia, No. Telp. 0341-551149
}

\begin{abstract}
ABSTRAK
Perbedaan Pengaruh Olahraga Terhadap Toleransi Stres Psikologis Mahasiswa Fakultas Kedokteran Universitas Muhammadiyah Malang. Latar Belakang: Stres yang dialami oleh mahasiswa kedokteran disebabkan oleh berbagai penyebab, meliputi metode pembelajaran, materi yang luas dan waktu pendidikan yang cukup lama. Tuntutan tersebut menyebabkan timbulnya stres psikologis dengan tingkatan yang bervariasi, mulai dari stres ringan, sedang dan berat. Olahraga bermanfaat tidak hanya untuk kesehatan fisik tetapi juga bermanfaat untuk kesehatan mental dan melatih respon terhadap kondisi stress. Tujuan: Membuktikan perbedaan aktivitas olahraga terhadap toleransi stres psikologis pada mahasiswa FK-UMM. Metode: Observasional analitik dengan rancangan cross-sectional. Sampel mahasiswa laki-laki FKUMM angkatan 2010 dan 2011 yang masuk dalam kriteria inklusi. Analisis data menggunakan unpaired t-test. Hasil Penelitian dan Diskusi: Hasil uji t-tidak berpasangan, didapatkan perbedaan yang bermakna antara pengaruh olahraga dengan toleransi stres psikologis mahasiswa FK-UMM yaitu dengan nilai sig $=0.001(\mathrm{p}<0.05)$. Faktor BDNF dan Beta-Endorfin memiliki pengaruh yaitu meningkatkan respon seseorang terhadap stres psikologis. Kesimpulan: Terdapat perbedaan pengaruh aktivitas olahraga terhadap toleransi stres psikologis mahasiswa FK-UMM.
\end{abstract}

Kata Kunci: Aktivitas Olahraga, Toleransi Stres Psikologis, Mahasiswa FK-UMM.

\begin{abstract}
The Difference Between The Influence of Physical Activity to Psychological Stress Tolerance on Medical Students of Faculty of Medicine of University of Muhammadiyah Malang. Backgrounds: Stress on the medical students caused by many factors, including curriculum method, huge materials and years of study. Those factors could caused psychological stress with degrees of variance which consist from mild, moderate, and severe. Physical activity like sports had beneficial effects to mental health and enhanced to the respond of stress. Goal: To prove the difference between the influence of physical activity to psychological stress tolerance on medical students of Faculty of Medicine UMM. Method: The method used analytic observational with cross-sectional study approach. Sampel consist of the men's students of Faculty of Medicine of UMM, the third and fourth degree, based on inclusion criteria. Data analyzed with unpaired t-test. Result and Discussion: The result of unpaired t-test shown that there was meaned difference between the influence of physical activity and psychological stress tolerance with $p=0.001(p<0.05)$. BDNF and Beta-Endorphin roled as the influencing factors by increasing the respond to psychological stress. Conclusion: There was a difference between the influence of physical activity to psychological stress tolerance on students of Faculty of Medicine of UMM.
\end{abstract}

Key words: Physical Activity, Psychological Stress Tolerance, Students of Faculty of Medicine of UMM

\section{PENDAHULUAN}

Stres adalah suatu kondisi yang menimbulkan perubahan fisik (biokimia, neurohormon dan imunitas) serta psikologis (kognitif dan perilaku) (Robbins, 2001). Stres yang berlebihan atau kontinu akan berdampak buruk yang menyebabkan timbulnya masalah mental seperti gangguan psikologis, emosi yang labil bahkan bunuh diri serta gangguan fisik yaitu beberapa penyakit kronis seperti gangguan kardiovaskular, muskuloskeletal, gastrointestinal, kanker dan penurunan imunitas (Shah et al., 2010). Proses stres merupakan suatu siklus berkelanjutan yang memiliki suatu mekanisme umpan balik (Weinberg, 2003). Mekanisme umpan balik tersebut memerlukan adaptasi atau toleransi yang baik terhadap stres. Seseorang dengan toleransi stres yang tinggi akan dapat bertahan dan beradaptasi dengan baik terhadap berbagai stressor, sedangkan seseorang dengan toleransi stres yang rendah tidak mampu beradaptasi terhadap stres dengan baik sehingga rentan mengalami distres (Semiun, 2006). Stres yang dialami oleh mahasiswa kedokteran disebabkan oleh berbagai stressor, yaitu stressor psikososial, stressor yang berhubungan dengan kesehatan dan stressor akademis. Stresor akademik meliputi metode pembelajaran, tuntutan penguasaan materi yang luas dan terintegrasi serta waktu pendidikan yang cukup lama. Metode 
pembelajaran menuntut mahasiswa mampu mengatasi masalah secara mandiri. Tuntutan terhadap penguasaan materi membuat sebagian besar mahasiswa menghabiskan waktunya untuk belajar sehingga tidak memiliki banyak kesempatan untuk berinteraksi serta berhubungan sosial dengan teman-teman dan masyarakat. Tuntutan tersebut menyebabkan timbulnya stress psikologis dengan tingkatan yang bervariasi yaitu dari stres ringan, sedang, berat hingga burnout banyak ditemukan pada mahasiswa kedokteran (Sherina, 2003).

Prevalensi stres psikologis yang terjadi di fakultas kedokteran lebih tinggi dibandingkan dengan fakultas lain. Hal itu didasarkan pada penelitian yang dilakukandi berbagai negara terhadap mahasiswa fakultas teknik dengan mahasiswa fakultas kedokteran. Di Adelaide, penelitian terhadap mahasiswa teknik menunjukkan bahwa $38.2 \%$ mahasiswa mengalami stres psikologis. Penelitian pada mahasiswa kedokteran menunjukkan hasil yang lebih tinggi. Penelitian yang dilakukan di salah satu perguruan tinggi di Malaysia terhadap seluruh mahasiswa kedokteran menyebutkan bahwa sebesar $41.9 \%$ mahasiswa kedokteran ditemukan mengalami stres psikologis. Selain itu di India dan Thailand, prevalensi stres psikologis yang dialami mahasiswa kedokteran sangat tinggi yaitu sekitar 73\% \& 61.4\% (Shah et al., 2010; Sherina et al., 2003). Berbagai upaya dapat dilakukan untuk mencegah mahasiswa mengalami distres, salah satunya melalui olahraga. Sejumlah bukti menyebutkan bahwa olahraga yang dilakukan secara rutin bermanfaat tidak hanya untuk kesehatan fisik tetapi juga bermanfaat untuk kesehatan mental dan melatih adaptasi terhadap kondisi stres (Raglin \& Wilson, 2012). Penelitian di Finlandia menunjukkan bahwa olahraga memiliki dampak positif terhadap $48.92 \%$ responden seperti menyebabkan penurunan depresi, emosi dan stres psikologis (Peter, 2000). Di Jerman, pada $63.82 \%$ responden ditemukan penurunan reaksi stres psikologis yang lebih baik pada wanita yang sangat aktif berolahraga dibandingkan dengan yang tidak pernah berolahraga (Klaperski et al., 2012). Penelitian di Pakistan menyebutkan prevalensi stres psikologis yang dialami mahasiswa laki-laki hanya sebesar 32.92\%. Jumlah itu jauh lebih kecil dibandingkan wanita, yaitu $67.08 \%$. Hal tersebut disebabkan oleh berbagai faktor hormonal dan pola hidup yang berbeda diantara keduanya. Berdasarkan latar belakang tersebut, peneliti tertarik untuk meneliti perbedaan aktivitas olahraga terhadap toleransi stres psikologis mahasiswa Fakultas Kedokteran Uniiversitas Muhammadiyah Malang.

Tujuan umum penelitian ini adalah untuk membuktikan perbedaan pengaruh olahraga terhadap toleransi stres psikologis mahasiswa Fakultas Kedokteran Universitas Muhammadiyah Malang. Sedangkan tujuan khususnya adalah menganalisis skoring toleransi stres menggunakan Inventory for Measuring Stress Tolerance (IMST) terhadap aktivitas olahraga mahasiswa laki-laki FK-UMM angkatan 2010 dan 2011, menganalisis skoring stres psikologis menggunakan Inventory for the Measurement of Psychosocial Stress (IMPS) terhadap aktivitas olaharaga mahasiswa laki-laki FK-UMM angkatan 2010 dan 2011, serta mengetahui jenis olahraga yang banyak dilakukan oleh mahasiswa laki-laki FK-UMM angkatan 2010 dan 2011.
Hasil penelitian ini dapat menambah khazanah keilmuan terhadap manfaat berolahraga bagi mahasiswa fakultas kedokteran. Manfaat penelitian secara klinis adalah untuk memberikan informasi bahwa olahraga dapat berperan dalam meningkatkan fungsi promotif dan preventif terhadap stres psikologis pada mahasiswa. Sedangkan manfaat di kalangan masyarakat untuk memberikan informasi mengenai gambaran toleransi stres pada mahasiswa fakultas kedokteran.

Harapan yang ingin dicapai penulis adalah olahraga memiliki dampak yang baik terhadap berkurangnya stress psikologis diantara mahasiswa FK.

\section{METODE}

Bahan pada penelitian ini menggunakan: data anamnesis, lembar informed consent penelitian, Inventory for measuring Stress Tolerance (IMST), dan Inventory for the Measurement of Psychosocial Stress (IMPS). Rancangan Penelitian ini menggunakan jenis penelitian observasi analitik dengan pendekatan cross sectional. Tempat dan Waktu Penelitianini bertempat di Lab Faal Fakultas Kedokteran Universitas Muhammadiyah Malang pada Bulan Juni tahun 2014. Populasi penelitian yaitu mahasiswa Fakultas Kedokteran Universitas Muhammadiyah Malang angkatan 2010 \& 2011. Sedangkan sampel penelitian adalah mahasiswa laki-laki Fakultas Kedokteran Universitas Muhammadiyah Malang Angkatan 2010 dan 2011. Sampel diambil secara total sampling.

Kriteria inklusi penelitian ini yaitu bersedia menjadi responden, mahasiswa laki-laki FK-UMM angkatan 2010 dan 2011, sehat secara mental (bebas dari penyakit gangguan jiwa seperti depresi berat dan gangguan mental), serta mahasiswa yang melakukan aktivitas olahraga aerobik, anaerobik maupun campuran. Sedangan untuk kriteria eksklusi penelitian adalah mahasiswa yang memiliki penyakit kronis yang mengganggu kesehatan mentalnya, mahasiswa yang mengalami masalah psikologis yang mengganggu kesehatan mentalnya, serta mahasiswa yang sedang mengkonsumsi obat antidepressant dan antipsikotik.

\section{HASIL DAN PEMBAHASAN}

Penelitan dilakukan pada mahasiswa laki-laki Fakultas Kedokteran Universitas Muhammadiyah Malang angkatan 2010 \& 2011 pada tanggal 4 Juni - 7 Juni 2014 yang bertempat di Laboratorium Faal Fakultas Kedokteran Universitas Muhammadiyah Malang. Sampel yang didapatkan adalah sebanyak 49 orang yang memenuhi kriteria inklusi yang telah ditetapkan sebelumnya.

Dari Gambar 1. tersebut menunjukkan bahwa $55.1 \%$ mahasiswa laki-laki FK-UMM angkatan 2010 \& 2011 melakukan kegiatan olahraga dan sebesar $44.9 \%$ tidak melakukan kegiatan olahraga. Untuk toleransi stresnya, dari mahasiswa yang berolahraga $89 \%$ memiliki toleransi stres yang tinggi dan sebesar $11 \%$ memiliki toleransi stres rendah. Bagi kelompok yang tidak berolahraga didapatkan sebesar 5\% mahasiswa memiliki toleransi stres yang rendah, 55\% bertoleransi stres sedang dan sebesar $40 \%$ memiliki toleransi stres yang tinggi. 
Grafik Persentase Olahraga Pada Mahasiswa

$$
\text { FK-UMM }
$$

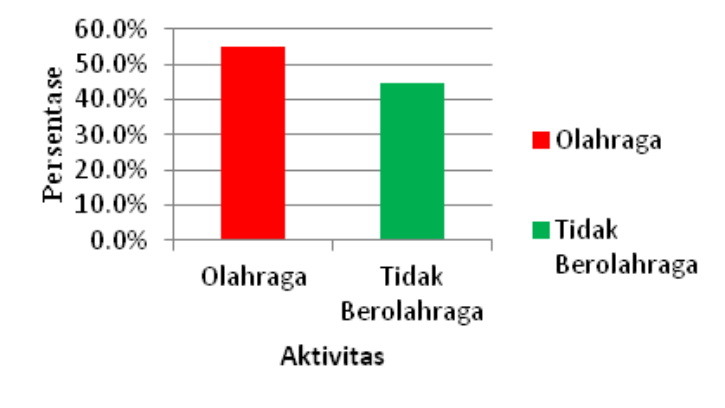

Mahasiswa FK-UMM

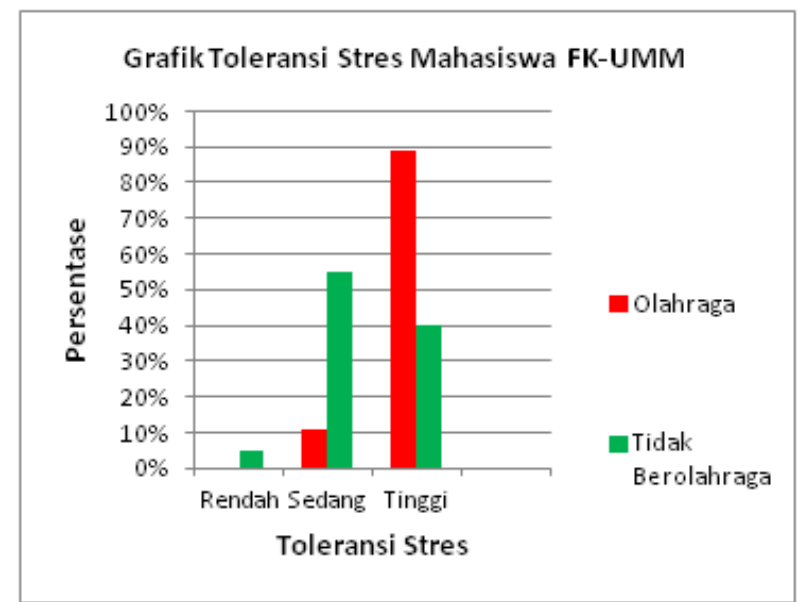

Gambar 2. Grafik Toleransi Stres Mahasiswa FKUMM

kemampuan sendiri untuk mengatasi masalah yang tengah dihadapi; dan (3) perasaan bahwa kita dapat mengendalikan atau berperan dalam mengangani situasi stres, berarti memiliki banyak alternatif tanggapan yang sesuai untuk menghadapi situasi yang menekan. Toleransi terhadap stres ini berkaitan dengan kemampuan untuk tetap tenang dan sabar, serta kemampuan menghadapi kesulitan dengan kepala dingin tanpa terbawa emosi (Stein \& Book, 2002).

Tabel 1. Presentase Skoring IMST dan IMPS

\begin{tabular}{lcccc}
\hline \multirow{2}{*}{ Keterangan } & \multicolumn{2}{c}{ Jumlah } & \multicolumn{2}{c}{ Persentase } \\
\cline { 2 - 5 } Kegiatan & Olahraga & Tidak Berolahraga & Olahraga & Tidak Berolahraga \\
Total & 27 & 22 & $55.10 \%$ & $44.90 \%$ \\
Toleransi Stres & & & & $100 \%$ \\
Toleransi rendah & 0 & 49 & & \\
Toleransi sedang & 3 & 1 & $0 \%$ & $5 \%$ \\
Toleransi tinggi & 24 & 9 & $11 \%$ & $55 \%$ \\
Total & 27 & 22 & $89 \%$ & $40 \%$ \\
Tingkat Stres & & & $100 \%$ & $100 \%$ \\
Tingkat stres rendah & 16 & 10 & & \\
Tingkat stres sedang & 11 & 12 & $59 \%$ & $45 \%$ \\
Tingkat stres berat & 0 & 0 & $41 \%$ & $55 \%$ \\
Total & 27 & 22 & $0 \%$ & $0 \%$ \\
\hline
\end{tabular}


Tabel 2. Jenis Olahraga pada Mahasiswa Laki-Laki FK UMM

\begin{tabular}{cccc}
\hline Olahraga & Jenis & Jumlah & Persentase \\
\hline Aerobik (A) & Lari & 1 orang & $3,7 \%$ \\
& Bersepeda & 2 orang & $7,4 \%$ \\
Anaerobik (AN) & Badminton & 1 orang & $3,7 \%$ \\
& Fitness & 4 orang & $14,8 \%$ \\
& Basket & 4 orang & $14,8 \%$ \\
Fampuran & Futsal & 10 orang & $37 \%$ \\
& Renang+Voli & 1 orang & $3,7 \%$ \\
& Renang+Futsal & 2 orang & $7,4 \%$ \\
& Renang+Badminton & 1 orang & $3,7 \%$ \\
& Futsal+Lari & 1 orang & $3,7 \%$ \\
& Total & 27 orang & $100 \%$ \\
\hline
\end{tabular}

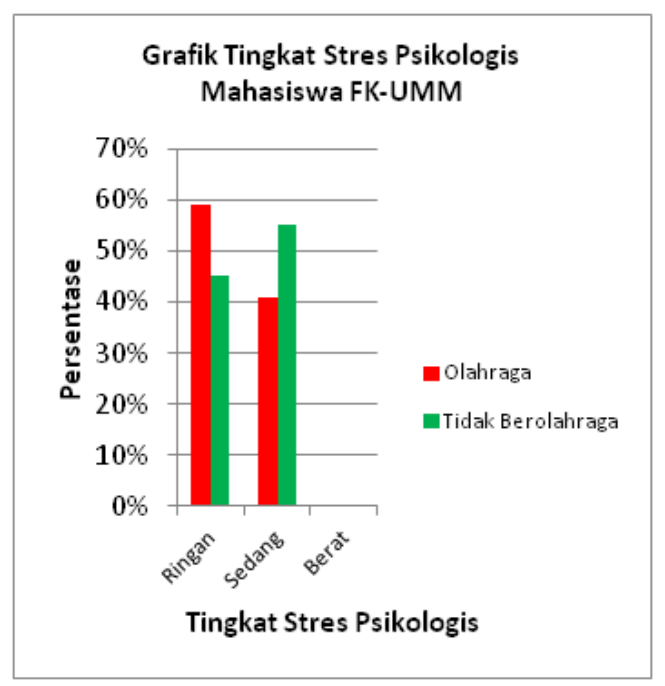

Gambar 3. Grafik Tingkat Stres Psikologis Mahasiswa FK-UMM

Dari data di atas, untuk tingkat stresnya, dari mahasiswa yang berolahraga, 59\% mengalami stres psikologis yang ringan dan sebesar $41 \%$ mengalami stres psikologis sedang. Kemudian untuk kelompok yang tidak berolahraga, 45\% mengalami stres psikologis yang ringan dan sebesar 55\% mengalami stress psikologis sedang. Jenis kegiatan olahraga yang dilakukan oleh mahasiswa laki-laki FK-UMM adalah olahraga aerobik dan olahraga anaerobik. Dari data di atas didapatkan data bahwa jenis olahraga yang paling banyak dilakukan adalah futsal yaitu $37 \%$, disusul basket dan fitness masing-masing sebesar 14.8\%.

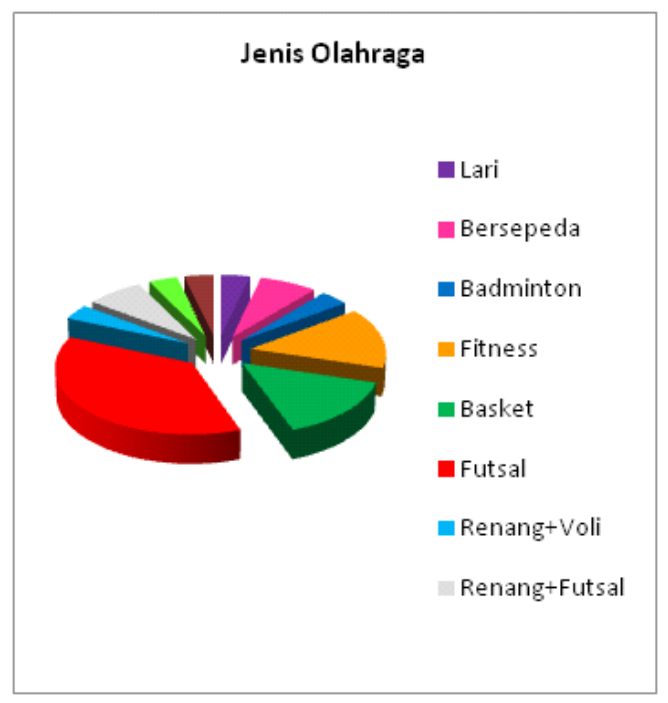

Gambar 4. Jenis Olahraga Pada Mahasiswa FK$\mathrm{UMM}$

Tabel 3. Uji Statistik Penelitian

\begin{tabular}{|c|c|c|c|c|}
\hline \multirow[b]{2}{*}{ Komponen } & \multirow[b]{2}{*}{ Uji Statistik } & \multicolumn{2}{|c|}{ Signifikansi } & \multirow[b]{2}{*}{ Keterangan } \\
\hline & & Olahraga & $\begin{array}{c}\text { Tidak } \\
\text { Berolahraga }\end{array}$ & \\
\hline \multicolumn{5}{|c|}{ Toleransi Stres (IMST) } \\
\hline $\begin{array}{l}\text { Uji } \\
\text { Normalitas }\end{array}$ & Shapiro-Wilk & 0.498 & 0.433 & $\begin{array}{l}\text { Distribusi } \\
\text { Data } \\
\text { Normal }\end{array}$ \\
\hline $\begin{array}{l}\text { Uji } \\
\text { Homogenitas }\end{array}$ & Levene & 0.038 & & $\begin{array}{l}\text { Data } \\
\text { Homogen }\end{array}$ \\
\hline $\begin{array}{l}\text { Uji } \\
\text { Komparasi }\end{array}$ & $\begin{array}{l}\text { Unpaired T- } \\
\text { Test }\end{array}$ & 0,000 & 0.001 & $\begin{array}{l}\text { Terdapat } \\
\text { Perbedaan } \\
\text { yang } \\
\text { Bermakna }\end{array}$ \\
\hline \multicolumn{5}{|c|}{ Tingkat Stres Psikologis (IMPS) } \\
\hline $\begin{array}{l}\text { Uji } \\
\text { Normalitas }\end{array}$ & Shapiro-Wilk & 0.001 & 0.101 & $\begin{array}{l}\text { Distribusi } \\
\text { Data Tidak } \\
\text { Normal }\end{array}$ \\
\hline $\begin{array}{l}\text { Uji } \\
\text { Transformasi }\end{array}$ & Transformasi & 0.371 & 0.162 & $\begin{array}{l}\text { Distribusi } \\
\text { Data } \\
\text { Normal }\end{array}$ \\
\hline $\begin{array}{l}\text { Uji } \\
\text { Homogenitas }\end{array}$ & Levene & 0.031 & & $\begin{array}{l}\text { Data } \\
\text { Homogen }\end{array}$ \\
\hline $\begin{array}{l}\text { Uji } \\
\text { Komparasi }\end{array}$ & $\begin{array}{l}\text { Unpaired T- } \\
\text { Test }\end{array}$ & 0.852 & 0.857 & $\begin{array}{l}\text { Tidak } \\
\text { Terdapat } \\
\text { Perbedaan } \\
\text { yang } \\
\text { Bermakna }\end{array}$ \\
\hline
\end{tabular}


Pada pengukuran toleransi stress didapatkan data sebagai berikut: Nilai signifikansi $\mathrm{p}=0.498,0.433(\mathrm{p}>$ $0.05)$, maka distribusi data normal. Nilai signifikansi $\mathrm{p}=$ 0.038 ( $p>0.01$ ), maka datanya homogen. Syarat untuk uji parametrik, uji t tidak berpasangan adalah distribusi data harus normal dan datanya homogen. Uji komparasi menggunakan uji parametrik yaitu uji t tidak berpasangan. Nilai $\mathrm{p}$ dengan signifikansi $\mathrm{p}=0.001$. Maka dapat ditarik kesimpulan terdapat perbedaan yang bermakna antara Olahraga dengan Toleransi Stres Psikologis mahasiswa FKUMM.

Sedangkan mengenai tingkat stress psikologis didapatkan data sebagai berikut : Nilai signifikansi $\mathrm{p}=$ 0.001, 0.101 ( $\mathrm{p}<0.05$ ), maka distribusi data tidak normal. Karena distribusi data tidak normal, dilakukan transformasi data. Setelah dilakukan transformasi data, distribusi data normal $(p=0.371,0.162)$. Nilai signifikansi $p=0.031(p>$ 0.01 ), maka datanya homogeny, jadi tetap dilakukan ujiparametrik. Dengan uji T-test Tidak Berpasangan, diperoleh angka signifikansi 0.852 . Karena nilai $>0.05$, dapat disimpulkan tidak terdapat perbedaan yang bermakna antara Olahraga dengan Tingkat Stres Psikologis mahasiswa FKUMM.

Pada penelitian ini telah terbukti bahwa olahraga berpengaruh terhadap toleransi stres yaitu pada orang yang berolahraga didapatkan memiliki toleransi stres lebih tinggi dibandingkan yang tidak berolahraga. Pada penelitian ini juga tidak terdapat hubungan antara olahraga dengan tingkat stres. Selain itu, didapatkan hasil penelitian bahwa olahraga yang paling banyak digemari adalah olahraga yang bersifat anaerobik (seperti futsal, basket dan fitness) dibandingkan dengan olahraga aerobik.

Orang yang berolahraga memiliki toleransi stres yang tinggi. Hal ini disebabkan karena pada orang yang berolahraga, kadar BDNF (Brain- derived neurothropic factors) dan Beta-Endorphinsnya meningkat. BDNF berperan dalam meningkatkan kadar Long Term Potentiation (LTP) yang mendukung terjadinya plastisitas saraf sehingga meningkatkan fungsi memori dan pembelajaran yang pada akhirnya menyebabkan peningkatan toleransi terhadap stres (Yang et al., 2005). Beta-Endorphins berperan dalam menurunkan kadar kortisol berlebih sehingga dapat menyebabkan kadar kortisol menjadi normal kembali. Kadar kortisol yang normal mengembalikan fungsi CRHR2 sehingga dapat meningkatkan fungsi kognisi dan emosi individu. Fungsi kognisi dan emosi yang membaik akan menyebabkan peningkatan toleransi stres individu (Xiao et al., 2013).

Pada kondisi stres yang kronis, terjadi peningkatan kortisol yang berlebih di dalam tubuh dan terjadi penurunan kadar BDNF di hipokampus (regio CA1 \& CA3) dan amigdala. Kadar kortisol yang berlebih tersebut menurunkan respon CRHR2, sedangkan penurunan terhadap kadar BDNF menyebabkan menurunnya fungsi plastisitas. Penurunan respon CRHR2 dan kadar beta endorfin tersebut menyebabkan penurunan toleransi terhadap stres (Xiao et al, 2013). Oleh sebab itu dengan berolahraga, individu dapat meningkatkan toleransi stresnya dan pada akhirnya mampu terhindar dari keadaan distres (Xiao et al, 2013).
Penelitian terdahulu membuktikan bahwa BDNF memiliki pengaruh yang signifikan terhadap peningkatan toleransi stres. Penelitian yang dilakukan oleh Cotman \& Berchtold menyebutkan bahwa pada bagian hipokampus yang dipaparkan sinar densitas tinggi menyebutkan bahwa terjadi peningkatan kadar BDNF yang lebih tinggi pada tikus yang diberikan perlakuan olahraga dibandingkan dengan yang tidak diberikan perlakuan olahraga (Cotman \& Berchtold, 2002).

Penelitian lainnya oleh yang juga menyebutkan bahwa BDNF berpengaruh terhadap peningkatan toleransi stres melalui respon memori dan pembelajaran yang lebih baik pada tikus. Pada tikus yang yang diberikan perlakuan olahraga 2 minggu, secara signifikan memiliki fungsi pembelajaran dan recall yang lebih baik dalam menemukan lokasi sebelumnya daripada yang tidak diberikan perlakuan (Vaynman et al., 2004). Penelitian yang terakhir juga menjelaskan bahwa peningkatan BDNF pada orang yang berolahraga sangat aktif yaitu terjadi peningkatan kadar BDNF sebesar 45\%, sedangkan pada individu yang jarang berolahraga terjadi penurunan kadar BDNF sebesar 13\%(Matthew, 2013).

Pada penelitian-penelitian terdahulu telah disebutkan peran Beta-Endorphins yang sangat penting dalam meningkatkan toleransi stres. Pada kelompok tikus yang diberikan perlakuan olahraga, setelah 2 jam menunjukkan tikus yang berolahraga kadar Beta-Endorphins nya tinggi dan kortisol yang berlebih menjadi turun sehingga kadar kortisol menjadi baik untuk merespon terhadap stres (Xiao et al., 2013).

Lain halnya dengan toleransi stres, olahraga tidak berpengaruh terhadap tingkat stres psikologis. Hal itu karena tingkat stres psikologis dipengaruhi oleh beberapa faktor yaitu dukungan sosial, karakter dan kepribadian individu, faktor kompetisi diantara individu yang berolahraga dan masa recovery (istirahat) (Yamamoto, 2004).

Penelitian oleh Shah menyebutkan bahwa mahasiswa yang tidak mendapatkan dukungan sosial yang cukup, baik dari keluarga ataupun kerabat, memiliki tingkat stres psikologis yang tinggi. Mahasiswa menghadapi banyak masalah dan rintangan ketika menjalani studi. Ketika tidak ada seseorang yang dapat membantu atau mendukungnya dalam menyelesaikan suatu masalah, hal itu dapat menyebabkan timbulnya tekanan hingga pada akhirnya dapat menimbulkan stres psikologis pada mahasiswa tersebut (Shah et al, 2010). Selain itu, faktor kepribadian dan karakter individu yang bermacam-macam juga dapat menyebabkan timbulnya tingkat stres psikologis yang bervariasi. Individu yang menyikapi masalah dengan positif dan tidak mudah menyerah mengalami tingkat stres psikologis yang lebih rendah dibandingkan dengan individu yang menyikapi masalah dengan negatif atau penuh emosi (Emery, 2013).

Penelitian oleh Rimmele menunjukkan bahwa aktivitas fisik seperti olahraga tidak menurunkan tingkat stres psikologis seseorang. Hal ini dikarenakan adanya keinginan untuk dapat menguasai suatu olahraga dan faktor kompetisi sehingga menyebabkan timbulnya stres psikologis diantara individu yang berolahraga tersebut (Rimmele et al., 2009).

Penelitian lainnya menyebutkan bahwa olahraga tidak dapat menurunkan tingkat stres psikologis seseorang 
diakibatkan karena aktivitas olahraga yang dilakukan individu terlalu berlebihan sehingga menyebabkan individu mengalami keletihan. Keletihan tersebut dapat meningkatkan stres yang dihadapi apalagi jika ditambah dengan kurangnya masa recovery (akibat kurangnya waktu tidur, pekerjaan yang menumpuk serta tuntutan lainnya). Hal tersebut mempengaruhi keadaan psikologis seseorang sehingga dapat memicu timbulnya stres psikologis (Meeusen et al., 2006).

Selain mengetahui gambaran toleransi dan tingkat stres psikologis mahasiswa, penelitian ini juga bermaksud untuk mengetahui gambaran jenis olahraga yang digemari mahasiswa dan pengaruhnya terhadap toleransi stres psikologis. Pada penelitian ini diperkirakan ada hubungan antara jenis olahraga dengan toleransi stres psikologis individu. Jenis olahraga yang digemari oleh mahasiswa adalah olahraga anaerobik (seperti futsal, fitness, dan basket) daripada olahraga aerobik (bersepeda, berenang dan berlari).

Penelitian yang dilakukan oleh Meyer menyebutkan bahwa telah dilakukan penelitian terhadap beberapa responden. Responden diminta untuk berolahraga di alat ergocycle lalu setelah 20 menit diukur kadar Beta-Endorfinnya. Kadar Beta-Endorfin yang dibandingkan adalah sebelum berolahraga dan setelah berolahraga. Ternyata didapatkan data bahwa yang melakukan aktivitas ergocycle dengan aktivitas aerobik ataupun aerobik selama 20-30 menit didapatkan peningkatan kadar beta-endorfin yang signifikan dari keduanya (Meyer et al., 2000). Penelitian lainnya menunjukkan bahwa terjadi peningkatan kadar BDNF dan Beta-Endorfin yang lebih tinggi pada individu yang melakukan jenis olahraga anaerobik dibandingkan dengan jenis olahraga aerobik. Peningkatan yang cepat itu disebabkan oleh proses metabolisme pada olahraga anaerobik lebih cepat dibandingkan dengan olahraga aerobik yang ditandai dengan peningkatan sirkulasi peredaran darah sehingga kadar BDNF dan Beta-Endorfin yang dihasilkan jauh lebih banyak (Winter et al, 2006).

Berdasarkan teori, peningkatan kadar BDNF maupun Beta-Endorfinnya lebih tinggi pada olahraga anaerobic daripada olahraga aerobik. Tetapi perlu dilakukan penelitian lebih lanjut untuk dapat mengetahui jenis olahraga mana yang lebih baik dalam meningkatkan toleransi terhadap stres psikologis individu.

\section{KESIMPULAN}

Berdasarkan hasil dan pembahasan penelitian, dapat diambil kesimpulan bahwa terdapat perbedaan yang bermakna antara pengaruh olahraga dengan toleransi stres pada mahasiswa laki-laki FK-UMM, sedangkan hubungan antara pengaruh olahraga dengan tingkat stres psikologis tidak terdapat perbedaan yang bermakna. Jenis olahraga yang paling banyak dilakukan adalah futsal yaitu $37 \%$, disusul basket dan fitness masing-masing 14.8\%.

\section{DAFTAR PUSTAKA}

\section{(Jurnal)}

Booth, M.L., Okely, A.D., Chey, T., Bauman, A., \& Macaskill, P.(2002). Epidemiology of physical activity participation amongNew South Wales school students. Australian and New ZealandJournal of Public Health 26:371-374

Cotman \& Berchtold. 2002. Exercise : A Behavioral Intervention to Enhance Brain Health \& Plasticity. Elseveir : California. TRENDS in Neuroscience Vol 25 No.6

David, Jackson \& Kalin, N. H. 2000. Emotion, plasticity, context, and regulation: Perspective from affective neuroscience. Psychological Bulletin, 126, 890-909.

\section{(Buku)}

Ader, R. 2001. Psikoimunologi $3^{\text {td }}$ ed. Vol 12. Academic Press : USA

Allen, Goldfarb. 2013. Endocrinology of Physical Activity adn Sport : Exercise and Endogenous Opioates. Springer Science+Business Media : New York.

Biddle S.J. 2000. Physical Activity and Psychological Well-Being. London : Routledge.

Brannon, Linda., Feist,Jess. 2007. Health Psychology :AnIntroductiontoBehaviorand Health. Belmont,USA.

Carruthers, 2006. Massive Modularity and the Flexibility of Though. Oxford University Press. Maryland

Chaplin, J.P. 2006. Kamus Lengkap Psikologi (terjemah Kartini Kartono). Jakarta: PT. Raja Grafika Persada

Coalter, F., Allison, M. \& Taylor, J. 2000. The Role of Sport in Regenerating Deprived Urban Areas. The Scottish Executive Central Research Unit: Edinburgh

Davey, K. 2010. A Unique Assessment of Stress and Stress Factors on Engineering Academics in The Research and Teaching Environment. University of Adelaide : Australia

Emery, R. \& Oltmanns, F. 2013. Psikologi Abnormal. Pustaka Pelajar : Yogyakarta. pp. 276-279

Goldfarb, Allan. 2013. Endocrinology of Physical Activity adn Sport : Exercise and Endogenous Opioates. Springer Science+Business Media : New York. 